\title{
Festtale til 44. årsmøde i Dansk Selskab for Statskundskab
}

\author{
Kasper Møller Hansen \\ Formand for Dansk Selskab for Statskundskab, Professor, Institut for Statskundskab, \\ Københavns Universitet.
}

\section{Indledning}

Dansk Selskab for Statskundskab er stiftet i 1960 og holder årligt en to dages konference. I de seneste år har den været afholdt i Vejle med ca. 100 deltagere. Deltagerne er hovedsageligt forskere fra de politologiske miljøer i Danmark, men er åben for andre deltagere. Der er en tradition for at der ved middagen under konferencen afholdes en festtale, som tager specifikke emner op. Talen i 2012 fokuserede på den enorme produktivitetsfremgang i dansk statskundskab målt på videnskabelige internationale artikler. Samtidige blev talen brugt til at tildele professor Jørgen Elklit Erik Rasmussen-prisen, som blev uddelt for første gang.

\section{Festtalen ved det 44. årsmøde i Dansk Selskab for Statskundskab, 25.-26. oktober 2012}

Der var engang et lille kongerige, som ikke lod sig synderligt påvirke af udviklingen omkring sig. Fokus var på dansksprogede bøger og statskundskaben bidrog samlet kun med en enkelt eller to internationale artikler om året. I dag holder kongeriget det 44. årsmøde i Dansk Selskab for Statskundskab og meget vand er løbet i åen siden de første internationale artikler fra dansk statskundskab så dagens lys.

Statskundskaben er og har været i en rivende udvikling. Hvis vi ser på omfanget af internationale, publicerede artikler, har vi her omkring bordene sammen med vores kolleger publicerede næste 100 internationale artikler sidste år, og det er stærkt stigende, og i bedre og bedre tidsskrifter - fx fire artikler i American Political Science Review - inkl. et par, der er på vej. Blot for 10 år siden blev der kun publiceret ca. 25 internationale artikler årligt - altså en firedobling på bare 10 år. $^{2} \mathrm{Ja}$ - vi er blevet flere og feltet er vokset, men én firedobling på bare
10 år, er der få der kan matche. Selv hvis vi går til Kina blev deres bruttonationalprodukt kun fordoblet i samme periode. Qatar, verdens rigeste land, kan prale af en tredobling af deres BNP i perioden. Men ingen kommer i nærheden af vores lille kongeriges firedobling.

Men som statskundskaber giver man jo ikke så let op, så det er faktisk lykkedes mig at finde enkelte eksempler på andre firedoblinger. Fx sker der jævnligt en firedobling af ølsalget - hver gang der er landskamp firedobles ølsalget. Når temperaturen nærmer sig de 30 grader - firedobles salget af koldskål. Så vi er ikke helt alene. Men da vi ikke har landskampe og det er sjældent at temperaturen nærmer sig de 30 grader i vores kontorer er det nok ikke forklaringen på vores kongeriges store produktivitetsfremgang.

Ja vel - vi er flere, men det kan dog ikke forklare firedoblingen på de seneste 10 år. Her er forklaringen nok snarere - samarbejde! - inden for vores egne små institutkongeriger og med udenlandske kollegerne - spruder samarbejdsrelationerne. Vi skriver sjældnere og sjældnere alene, vi arbejder på nye og sjovere måder - vi arbejde sammen og udnytter hinandens forskellige kompetencer, og det skal vi blive endnu bedre til.

Og det er netop også her at selskabet og dens Årsmøde kommer til sin ret. Her kan generationer mødes og ideer kan opstå og blive udfordret. Jeg er især glad for at så mange ph.d.-studerende er her i dag. For ikke mindst at udbygge deres indenlandske forskningsnetværk. På den måde er Årsmødet også med til at åbne vores øjne for, hvad der sker i vores egen lille andedam, og kan på den måde være med til at styrke samarbejdet på tværs af institutter og udfordre den indavl, som vores institutkongeriger stadig er alt for meget præget af. 
Vores kongeriges fokusering på de internationale artikler - eller snarere de individuelle incitamentsstrukturer - har også en bagside. Vi skal huske på, at vi stadig er en branche, som er offentligt finansieret, og vi må ikke glemme at skrive på dansk til et dansk publikum, og hjælpe til i kommissioner, og stå til rådighed for offentligheden i såvel foredragssammenhæng samt svare på pressens mange spørgsmål. Synlighed kommer ikke af publicering i internationale tidsskrifter - synligheden fra de internationale artikler kan gøres op til, at de ca. 1.000 internationale artikler fra dansk statskundskab, er citeret i gennemsnit fire gange.

For at kunne fortsætte udviklingen skal vi altså huske vi er stærkere, når vi samarbejder, udveksler ideer og støtter hinanden og ikke mindst formår at udnytte kompetencerne på tværs af vores institutkongeriger.

\section{Tildeling af Erik Rasmussen-prisen til Jørgen Elklit}

Netop med disse evner for øje er det med særligt glæde jeg kan introducere Erik Rasmussen-prisen, som frem over vil blive uddelt hvert andet år her på årsmødet. Historikeren Erik Rasmussen var på mange måder dansk statskundskabs „founding father" og hans væsentlige tobindsværk Komparativ Politik fra 1968-69 var obligatorisk læsningen blandt statskundskaber i en lang årrække. ${ }^{3}$ Erik Rasmussen-prisen er sat i verden for at styrke og hædre den ånd, som Erik Rasmussen bidrog med i dansk statskundskab i mange år og som stadigt lever blandt os.

Det er en hæderspris, som består af 25.000 kr. (skattefrit). Proceduren er, at miljøerne i statskundskab har indstillet kandidater, og så har selskabets bestyrelse diskuteret sig frem til en modtager af prisen. Og det har ikke været let at vælge mellem de personer, som blev indstillet. De havde alle på fornemste vis bidraget forskningsmæssige til statskundskaben i Danmark og internationalt, og på mange måder været et fyrtårn for yngre kolleger. Men der var dog én person, som ragede over dem alle, som gennem snart en menneskealder har været et forbillede for os alle. Både i forhold til formidling i offentligheden, forskningsmæssige publikationer og ikke mindst hjulpet et utalt af yngre forskere gennem tiderne med deres arbejde.

(Prisen tildeles Jørgen Elklit, der ønskes tillykke, red.): 'Jørgen du har været et fyrtårn i dansk statskundskab i mere end 40 år, du har publiceret mere end 20 bøger og mere end 50 internationale artikler i de bedste tidsskrifter. Du er anerkendt som en af verdens førende valgsystemseksperter og har hjulpet demokratier verden rundt i mere end 20 år. I retfærdighedens navn har du heller ikke været bange af dig - som da du tegnede en ekstra forsikring - da du vidnede mod Mugabe i Zimbabwe. Jørgen du har gennem hele din karriere haft en utrolig evne til at dele ud af din faglige viden i alle typer af medier - TV, radio, aviser og foredrag i forsamlingshuse og på gymnasier. Samtidigt har du varetaget centrale poster som institutbestyrer, redaktionsmedlem af Politica og været initiativtager til en lang række helt centrale antologier. Som indstillingen til modtagelse af prisen lyder:

„han er ... sandsynligvis den mest hjælpsomme mand i dansk statskundskab. Det er nærmest ubeskriveligt, hvor mange og hvor meget forskere og studerende igennem årene har nydt godt af Jørgen Elklits generøse 'åben-dør-politik'. Inden for dansk statskundskab er han bredt anerkendt for sin vilje og evne til at levere saglige, grundige og kritiske kommentarer på manuskripter og fungere som sparringspartner i forbindelse med store og små spørgsmål. Mange publikationer og beslutninger i dansk statskundskab ville have været mindre gennemtænkte og mere ufuldstændige, hvis ikke Jørgen Elklit havde beriget professionen med en så indsigtsfuld, pertentlig og hjælpsom personlighed."

\section{Noter}

1. Se Mogens N. Pedersen (2010) Dansk Selskab for Statskundskab gennem et halvt århundrede - en organisatoriskhistorisk beretning. Politica, 42(4):499-516.

2. Antallet af internationale artikler jf. søgning i Thomson Reuters Web of Science begrænset til Social Science Citation Index fra 1956 til i dag. Søgenøglen er address="Denmark" og inden for kategorien $=$ „Political Science“ . Søgningen er gennemført 23. oktober 2012. I alt blev der funder 1085 artikler, som i gennemsnit er citeret 4,05 gange. I 2011 blev der publiceret 97 artikler, mens der i 2001 blev publiceret 32 artikler. I 1991 var tallet 19 i 1981 syv og i 1971 to artikler.

3. Rasmussen, Erik (1968) Komparativ Politik 1. Haslev: Gyldendal. Rasmussen, Erik (1969) Komparativ Politik 2. Haslev: Gyldendal. 